\title{
Expert System Diagnosis of Television Damage with Depth First Search Method Using Vb.Net Programming Language
}

\author{
Dicky Surya Dwi Putra ${ }^{1}$ \\ ${ }^{1}$ Universitas Buddhi Dharma, Sistem Informasi,Banten, Indonesia
}

\section{SUBMISSION TRACK}

Accepted : January 2, 2018

Revision : February 6, 2018

Avalaible Online: February 27, 2018

KEYWORD

Expert System, Damage Television, Depth

First Search, VB.NET.

CORRESSPONDENCE

Telepon: 08567388599

E-mail: dsurya_eboh@yahoo.co.id

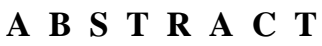

\section{INTRODUCTION}

Expert system is one of the scopes of artificial intelligence (artificial intelligent). One area of artificial intelligent that mimics the behavior of an or a group of experts in solving problems or damage. This expert system can analyze or diagnose the symptoms of damage, and provide conclusions of the damage that occurred and provide a solution of the damage that occurred to provide the steps and the tools needed to repair the damage. So the creation of an expert system was by collecting information from an expert with a knowledge book so that an expert system could diagnose the damage that occurred.

Television is an electronic item that has a lifespan. The age of a television is also determined by how a television user uses the television. There are people who like to care, there are also using television with a rough / not treated so shorten the age of television. Sometimes there are also people who have treated the television well but still damaged. This is due to electronic goods that can be damaged at any time. It could be damage occurs because when the assembly dipabrik, could be due to shaking during the delivery of television, and also because of the television users who do not care.Jika damage that can be done by putting consumers to warranty, but sometimes there is lazy because it takes a long time.But if the warranty has expired must be to the television service.Television of the latest fix the weakness of the television with the old model so that the damage to the new model television is less than the old model television. 
The television service is the place to fix the damaged television. But many television experts are fooling a consumer, for example there are items that are not being replaced only saggy but the television specialist mentions there is a broken television component. There are also frauds that often occur, for example only 1 component is broken but told the consumer there are 5 components or more so that the television expert gets a big profit from a broken television consumer. Consumers must be easily fooled because consumers themselves do not know what parts are broken and what are the components that are replaced by the type of damage.

To solve the problem, it was designed "Expert System Diagnosis of Color Television Damage Using Depth First Search Method Using VB.Net Programming Language". In this expert system the process of diagnosing it takes only a little time. In addition expert systems also help defective television users to know what damage is occurring and users can repair the damage. The expert system also teaches consumers to be able to correct the television that contains the steps and also the description of the image to make the

\section{DISCUSSION}

The system that has been running on the television service is to bring the television to the service and held a question and answer between television experts and television consumers. The question is about what experienced television before and after the damage, then continued the question of complaints experienced by television consumers. Then the television will be left to be diagnosed with the knowledge of the television specialist. Once diagnosed will be tested using a special tool for television. After the damage is known what happens then a television expert will replace the damaged television components. After replacing the damaged television compound it will be retested by turning on for several hours. After the television is fixed then the consumer will be informed by telephone or sms (short message service), then the consumer will consumer easy to follow the steps that must be done to repair the damage to television.

\section{Research Methodology}

The research methodology are:

1. Observation Method

The author will make an observation of an expert in the field of television. In addition the author will also review the way an expert in serving consumers.

2. Interview Method

At this stage the authors will interview people about the expert system on color television so that the results of interviews can refine the expert system that has been created by the author. By interviewing the knowledge base will increase, so the expert system can diagnose more accurately.

\section{Method Library}

In the process of designing, the author will also read books, articles and materials related to television damage that will be made by the author.

come to take the completed television repaired. When the customer comes to the service, the expert will inform the customer of the details and the expert will tell you why television can be damaged and provide a way to avoid damage as experienced by the consumer.

Much of what the television specialist faces is the general damage if television dies. Special damage is usually caused by human carelessness such as water spray, lightning strikes, falling. Special damage to an expert can be corrected because it requires special techniques to locate and replace damaged components.

The design of the database for this expert system built with a relationship model in which all tables are related to each other. 
The database design that contains the data used is as follows:

Expert decision tree on R1 damage (problems with television power)

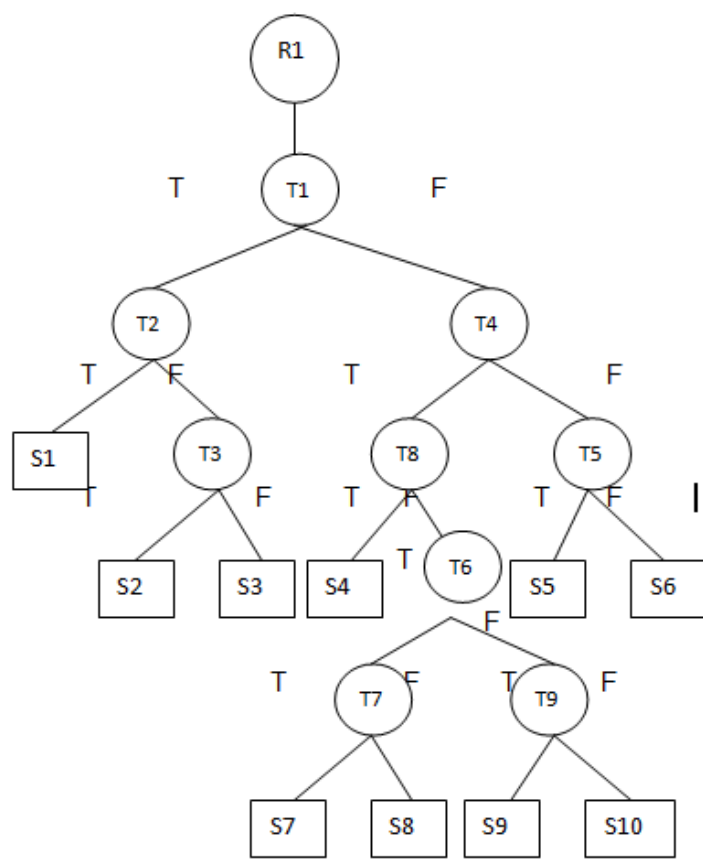

Expert decision tree on R2 damage (Television image problem)

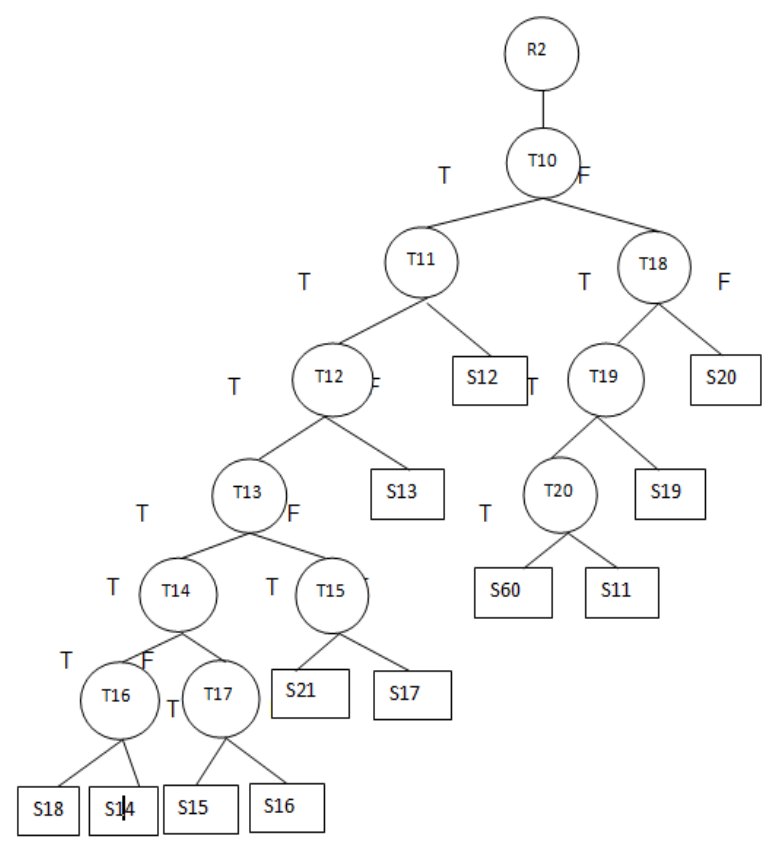

Expert decision tree $\mathrm{R} 4$ damage (horizontal and vertical display issues)

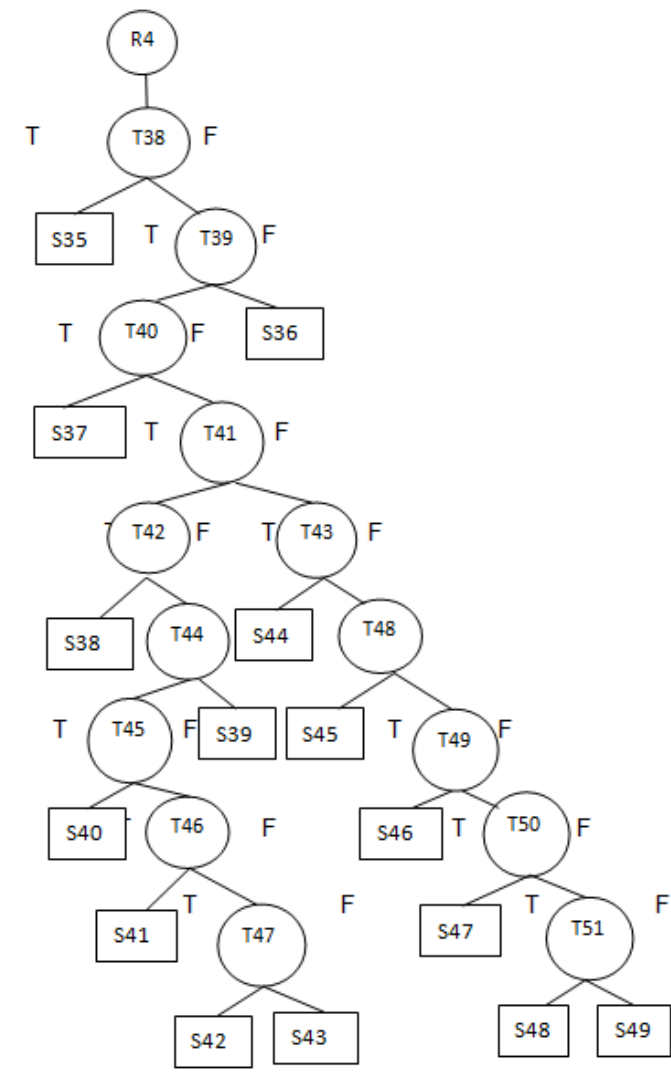

The decision tree expert damage R5 (television sound issue)

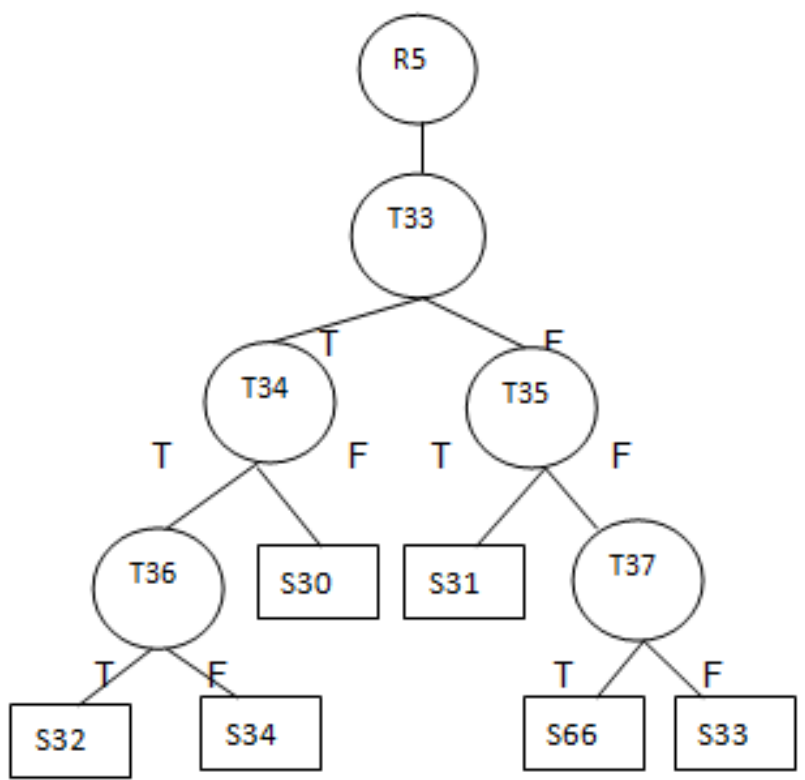


Versi Online tersedia di :http://jurnal.buddhidharma.ac.id/index.php/te

\section{JURNAL TECH-E}

| 2581-1916 (Online) | 2598-7585 (Printed) |

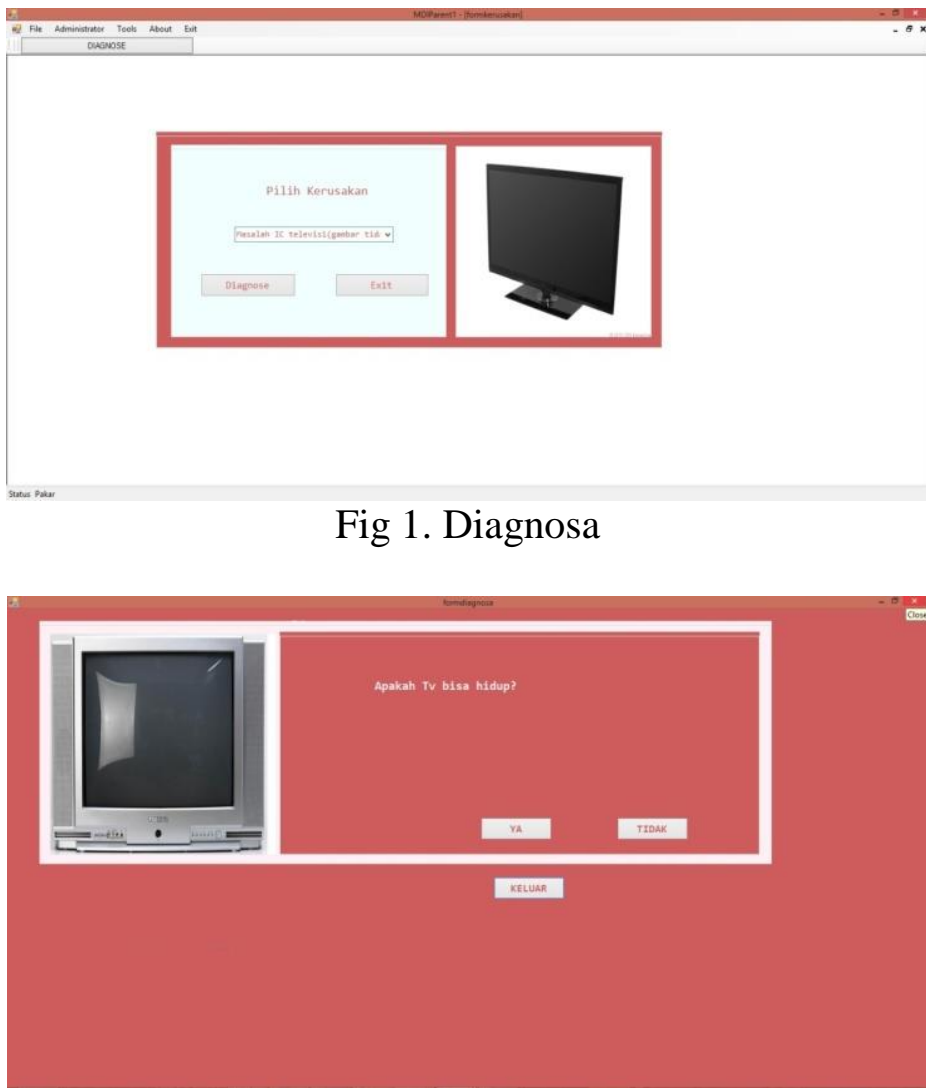

Fig 2. Questions Menu

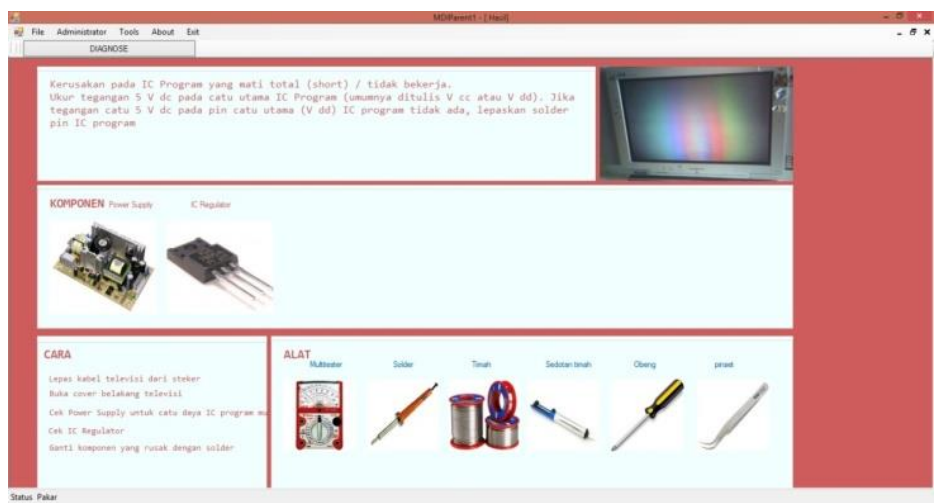

Fig 3. Solutions Menu 


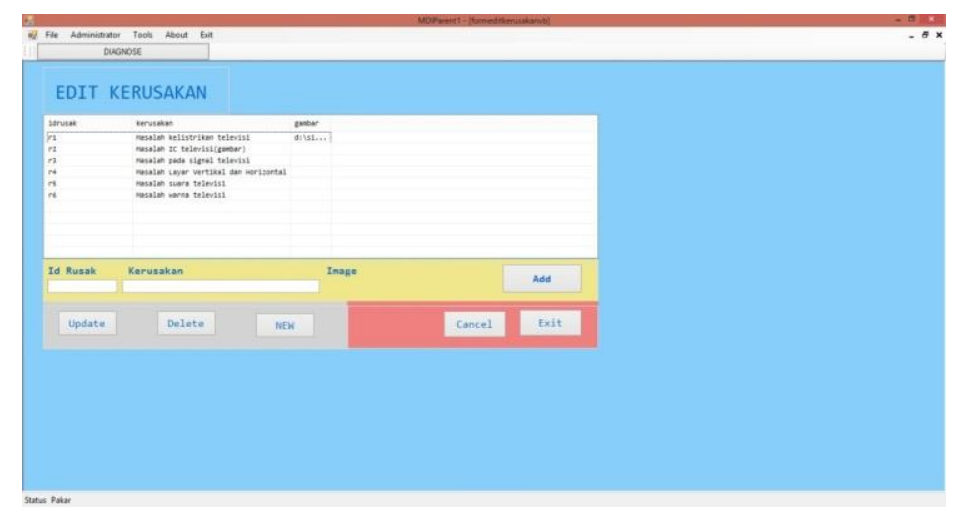

Fig 4. Damage Menu

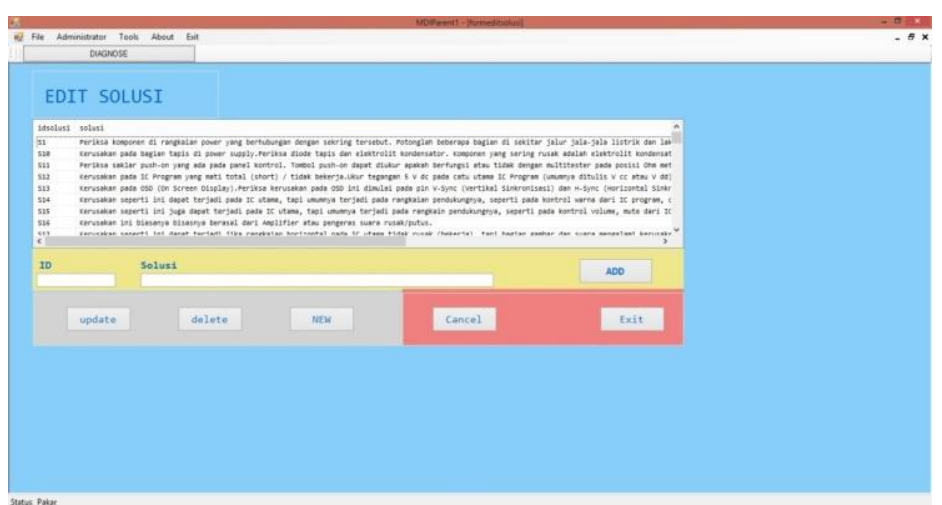

Fig 5. Solutions

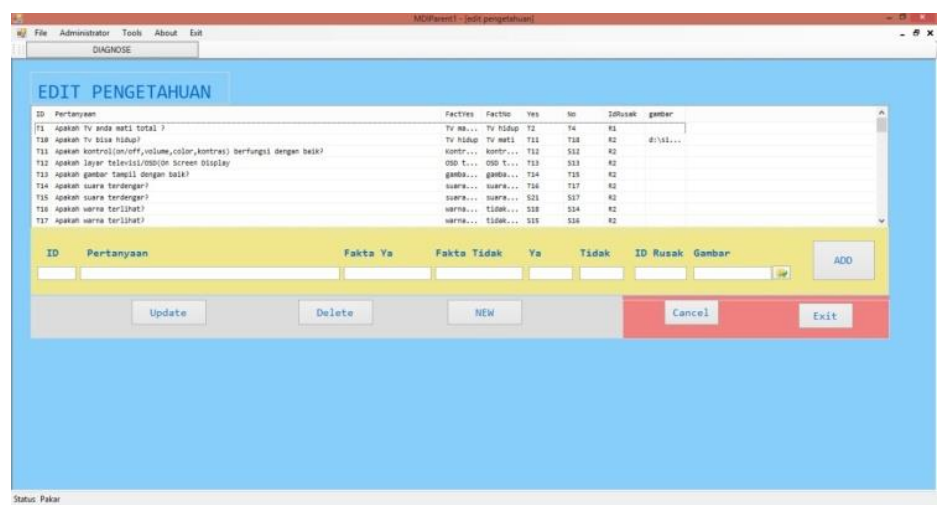

Fig 6. Knowledge Base

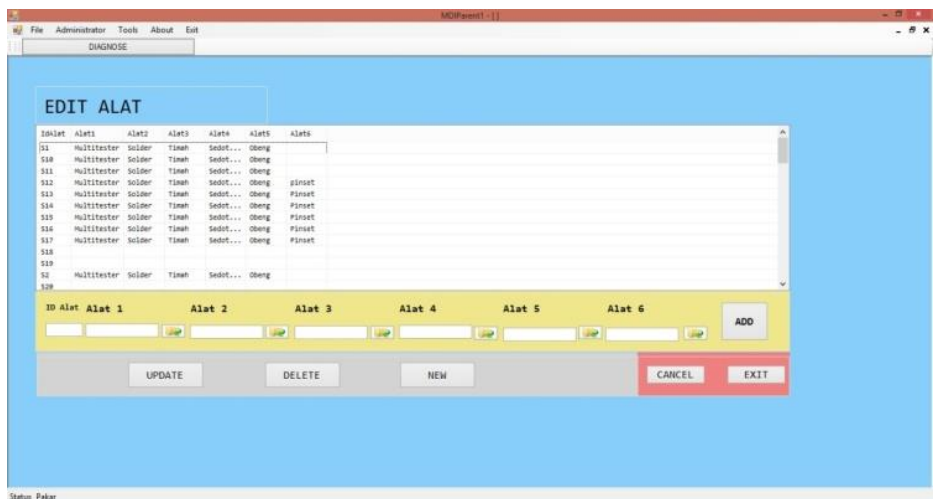

Fig 7. Tools 


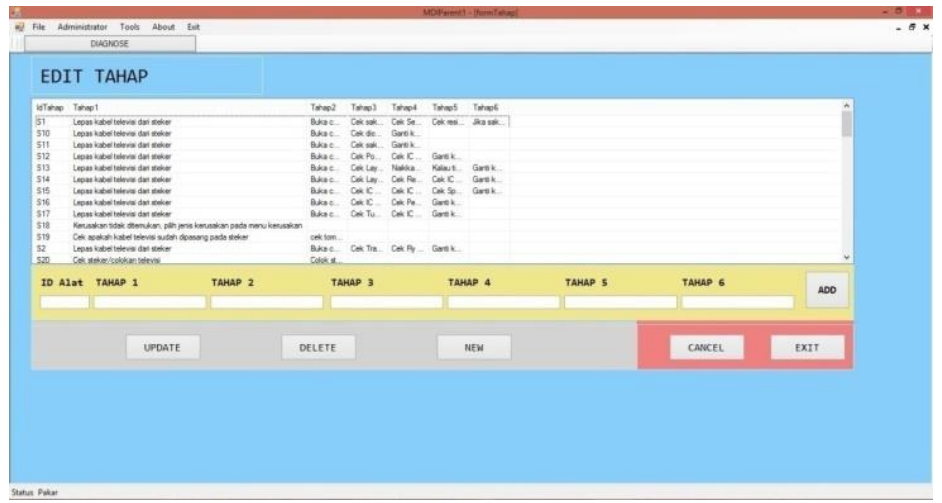

Fig 8. Step Analysis

\section{Results of Data Processing Kuisioner}

Once this expert system is created and implemented, it arrives at the evaluation stage. At this stage the expert system has been created and already tested directly and through the questionnaire at the value and evaluated. The questionnaire was given to 20 people who were given 10 questions. Here is the result of the questionnaire

Table 1. Responden

\begin{tabular}{|l|l|l|l|}
\hline No & Question & Y & N \\
\hline 1 & $\begin{array}{l}\text { Do you often operate a } \\
\text { computer }\end{array}$ & 18 & 2 \\
\hline 2 & $\begin{array}{l}\text { Have you ever used expert } \\
\text { system applications before? }\end{array}$ & 3 & 17 \\
\hline 3 & $\begin{array}{l}\text { Do you think this program } \\
\text { provides clear information }\end{array}$ & 14 & 7 \\
\hline 4 & $\begin{array}{l}\text { Do you think this app is easy } \\
\text { to use? }\end{array}$ & 16 & 4 \\
\hline 5 & $\begin{array}{l}\text { Do you think this app looks } \\
\text { interesting? }\end{array}$ & 12 & 8 \\
\hline 6 & $\begin{array}{l}\text { Do you think this application } \\
\text { needs to be developed again? }\end{array}$ & 10 & 10 \\
\hline 7 & $\begin{array}{l}\text { Do you think this expert } \\
\text { system can solve television } \\
\text { damage? }\end{array}$ & 12 & 8 \\
\hline 8 & $\begin{array}{l}\text { Are you interested in seeing } \\
\text { the development of this } \\
\text { expert system? }\end{array}$ & 14 & 6 \\
\hline 9 & $\begin{array}{l}\text { Can this application be useful } \\
\text { in the community? }\end{array}$ & 14 & 6 \\
\hline 10 & $\begin{array}{l}\text { Will this app be able to direct } \\
\text { the television? }\end{array}$ & 15 & 5 \\
\hline Sum & $63,5 \%$ & $36,5 \%$ \\
\hline$\%$ & r & 73 \\
\hline
\end{tabular}

This expert system of television damage diagnostics is enough to provide information and can direct users to improve the television that will be useful later in the community. In addition, this expert system needs to be developed again to improve the diagnosis of television damage.

\section{CONCLUSION}

After completing the creation of this expert system of television damage, it can be concluded that this application can be used as an application that can help someone in improving television. And also by using this application is also faster in diagnosing damage television. Accuracy results are quite high with Depth First Search method and the satisfaction level is reviewed through the questionnaire, with satisfaction reached $63.5 \%$ can be concluded this application can help in the television problem. 


\section{REFERENCE}

Andi. (2009). Pengembangan Sistem Pakar Menggunakan Visual Basic. C.V Andi, Yogyakarta. Hidayatullah, Priyanto. (2012). Visual Basic.NET Membuat Aplikasi Database dan Program Kreatif. Informatika, Bandung

Kurniawan, Erick. (2010). Cepat Mahir ASP.NET 3.5. C.V Andi, Yogyakarta

Prabawati, Arie. (2013). Membangun Aplikasi Database denan Visual Basic 2012. Wahana Komputer, Semarang

Rafea, Ahmed. Expert System Application : Agliculture. Egypt

Sadeli, Muhammad. (2012). Aplikasi SMS Dengan Visual Basic 6.0 \& Visual Basic 2010. Maxicom, Palembang

Sur, Abhishek. (2012). Visual Studio 2012 and .NET 4.5 Expert Development Cookbook. Packt enterpraise, Mumbai

Josephine, Yozia, and Riki Riki. "Implementasi eBudgeting Terhadap Kinerja PT Primer Eka Properti Melalui Pengendalian Internal." Tech-E 1, no. 1 (2017): 1-6.

\section{BIOGRAPHY}

Dicky Surya Dwi Putra, lahir di Tangerang pada 27 Juni 1987. Menyelesaikan pendidikan S1 (S.Kom.) di STMIK Buddhi dan pendidikan S2 (M.Kom.) di Eresha School of IT pada tahun 2012. Sekarang aktif sebagai dosen tetap di Universitas Buddhi Dharma sejak tahun 2009. 